\title{
ОБАЯНИЕ ВОСТОКА
}

DOI 10.15826/izv2.2019.21.1.016

УДК 745/749(520) + 7.036“189” + 069(470.5)

\author{
С. Е. Винокуров \\ 1) Екатеринбургский музей \\ изобразительных искусств \\ 2) Уральский федеральный университет \\ Екатеринбург, Россия
}

\section{ЯПОНСКАЯ ЭКСПОРТНАЯ ШИРМА: О ПРОЗРАЧНОСТИ КУЛЬТУРНЫХ ГРАНИЦ ВО ВТОРОЙ ПОЛОВИНЕ ХІХ - НАЧАЛЕ ХХ В.}

История художественных взаимоотношений Востока и Запада в отечественном искусствознании зачастую рассматривается в формате двух векторов: или «Восток - Запад», или «Запад - Восток», устанавливая тем самым некую границу между двумя художественными и, более широко, культурными парадигмами. Эта граница не только в некоторой степени ограничивает восприятие самой специфики подобных взаимодействий, обозначая лишь формат заимствований, но и сужает возможности понимания взаимного влияния культурных и художественных традиций, имеющих принципиально важное значение для искусства XIX в. Так, изучение отдельных произведений искусства, рассмотрение контекста их создания, истории дальнейшего бытования и т. д. позволяют раскрыть более сложный характер отношений художественных традиций Востока и Запада, разительно отличающийся от ситуации XVIII в. с его чрезмерной театрализацией и попыткой передать экзотичный характер через не менее экзотичные формы, колорит и сюжеты. В настоящей публикации рассматривается произведение японского декоративно-прикладного искусства одного из важнейших этапов истории страны Восходящего Солнца - эпохи Мэйдзи (1868-1912), поступившее в 2017 г. в собрание Екатеринбургского музея изобразительных искусств. Изучение этого произведения, необходимое для атрибуции, обусловило обращение к технологическим и стилистическим особенностям, а также потребовало обозначить возможный провенанс. Проведенное исследование дало возможность на конкретном примере рассмотреть специфику отношений европейской и дальневосточной традиций во второй половине XIX - начале XX в., основанную на перекрестном

(C) Винокуров С. Е., 2019

Известия УрФУ. Серия 2. Гуманитарные науки. 2019. Т. 21. № 1 (184) 
интересе, художественном обмене и опосредованном взаимном влиянии на возникновение новых идей и формирование направлений в искусстве.

К л ю ч е в ы е с л о в а: ширма; стиль Сибаяма; эпоха Мэйдзи; Екатеринбургский музей изобразительных искусств; коллекция К. К. Басевич; кросс-культурные связи; Европа; Восток.

Ц и т и р о в а н и е: Винокуров C. E. Японская экспортная ширма: о прозрачности культурных границ во второй половине XIX - начале XX в. // Изв. Урал. федер. ун-та. Сер. 2 : Гуманитар. науки. 2019. Т. 21. № 1 (184). С. 227-238.

Поступила в редакиию 18.10.2018

Принята к печати 09.01.2019

Sergey Ye. Vinokurov

1) Yekaterinburg Museum of Fine Arts

2) Ural Federal University

Yekaterinburg, Russia

\section{JAPANESE EXPORT SCREEN: \\ ON THE TRANSPARENCY OF CULTURAL BORDERS IN THE SECOND HALF OF THE $19^{\text {th }}-$ EARLY $20^{\text {th }}$ CENTURIES}

In Russian national art history, the evolution of art interrelation between East and West is often viewed through the prism of either the "East - West" or the "West - East" tradition, thus establishing a certain boundary between two artistic and, more generally, cultural paradigms. This border does not only limit the perception of the very specifics of such interactions to a certain extent, denoting only the format of borrowing, but also narrows the possibility of understanding the mutual influence of cultural and artistic traditions that are important for the art of the $19^{\text {th }}$ century. Meanwhile, if we analyse individual artworks in the context of their creation, it will help reveal more complex mechanisms of artistic traditions relationship. In this article, the author examines a sample of Japanese decorative and applied art related to one of the most important stages in the history of the Land of the Rising Sun, i.e. the Meiji period (1868-1912). This item entered the collection of the Yekaterinburg Museum of Fine Arts in 2017. To attribute this item properly, it was necessary to examine its technological and stylistic features and identify its possible provenance. The research conducted makes it possible to review the peculiarities of interrelation between European and Far Eastern traditions in the second half of the $19^{\text {th }}$ - early $20^{\text {th }}$ centuries, based on cross-interest and indirect mutual influence on the emergence of new ideas and the art trends formation.

K e y w o r d s: folding screen; shibayama style; Yekaterinburg Museum of Fine Arts; collection of K. K. Basewicz; Meiji period; cross-cultural communication; Europe; East.

C i t a t i o n: Vinokurov, S. Ye. (2019). Yaponskaia eksportnaya shirma: o prozrachnosti kulturnykh granits vo vtoroi polovine XIX - nachale XX v. [Japanese Export Screen: On the Transparency of Cultural Borders in the Second Half of the $19^{\text {th }}-$ Early 
C. Е. Винокуров. Японская экспортная ширма: вторая половина XIX - начало XX в. 229

$20^{\text {th }}$ Centuries]. Izvestia. Ural Federal University Journal. Series 2: Humanities and Arts, 21, 1 (184), 227-238.

Submitted on 18 October, 2018 Accepted on 09 January, 2019

В 2017 г. Екатеринбургский музей изобразительных искусств получил обширный дар от профессора Уральской архитектурно-художественной академии Рэны Михайловны Лотарёвой (1932-2018) [Владелица Красного коня]. В собрание музея Р. М. Лотарёва передала произведения, ранее входившие в собрание известного ленинградского коллекционера Казимиры Константиновны Басевич (1898-1973). Благодаря этому щедрому жесту собрание музея пополнилось работами К. С. Петрова-Водкина, Б. М. Кустодиева, 3. Е. Серебряковой, А. Н. Бенуа и других известных художников первой половины XIX в., а также четырьмя скульптурами и двумя сотнями предметов декоративноприкладного искусства, включающих мебель, фарфор конца XIX - первой половины XX в. европейских и дальневосточных производств, столовое серебро, художественное стекло, хрусталь и резной камень.

В немногочисленном ряду предметов мебели выделяется двустворчатая ширма в резной деревянной раме, обрамляющей два панно, выполненных в технике инкрустированного и живописного лака. В отличие от предметов изобразительного искусства, в разной степени подробности каталогизированных самим коллекционером, предметы прикладного искусства поступили в музей без какого-либо провенанса. На прижизненных фотографиях К. К. Басевич, запечатлевших обстановку дома и рассказывающих о расположении произведений живописи и графики в интерьере, заметна ширма, довольно органично вписавшаяся в общую творческую атмосферу квартиры, являвшейся в 1950-1960-е гг. своеобразной экспозицией русского искусства Серебряного века. Техническое совершенство этого предмета, стилистические нюансы, запутанный провенанс, а также контекст, в котором было создано и бытовало произведение стали поводом к детальному его изучению.

\section{Предмет}

Двустворчатая ширма (ил. 1, 2) при поступлении была идентифицирована как японское произведение конца XIX - начала XX в. [Владелица Красного коня, с. 144-145]. Такая атрибуция была сделана на основании изучения каталогов выставок, коллекций музеев и объявлений аукционных торгов. Ширма, несмотря на использование по прямому назначению на протяжении многих лет, сохранила оригинальную латунную фурнитуру - колесики на концах стоек и реверсивные петли, позволявшие менять по желанию направление изгиба конструкции, меняя и репрезентативный эффект произведения.

Массивные резные рамы из тонированного дерева, две стороны которых по-разному декорированы, демонстрируют высокий уровень работы японских 
мастеров с материалом. Декор рам в виде невысокого и выполненного с разной степенью детализации рельефа представляет композиции в традиционном жанре «катё-га» («картины о цветах и птицах») и отличается на «парадной» и «ординарной» сторонах ${ }^{1}$. Так, в верхней части «парадной» стороны рамы изображена раскрывшая крылья птица в окружении хризантем - традиционного символа Солнца, а также в ряде случаев императорской власти. В нижней части мастер представляет сочетание хризантемы с пионом - символом богатства, успеха и радости. На парадной стороне ширмы деревянная резная рама окаймляет вторую лаковую раму охристого оттенка с едва заметными пятнами более темного тона, имитирующими окрас иного материала (черепаховый панцирь, кожа или природный камень).

Центральным элементом «парадной» стороны ширмы являются панели глубокого темного синего цвета, выполненные в технике «иро-уруси» («цветной лак»), инкрустированные резными перламутром и костью. При внимательном осмотре заметно, что несколько утраченных элементов из кости в ходе старой реставрации были заменены на тонированные деревянные, но имитирующие стилистику резьбы.

Техника инкрустации перламутром или костью (реже - черепаховый панцирь, олений рог или кожа ската), называемая «радэн», была воспринята японскими мастерами из Китая и пережила несколько периодов. В период Мэйдзи эта техника стала едва ли не главным направлением творческой программы большинства мастерских Японии.

На центральных панно выполнены композиции в жанре «цвета и птицы». На правом панно инкрустацией элементов из резной кости создано предельно реалистичное изображение плетеной с прорехами и растрепанным нижним краем изгороди, служащей опорой для тянущихся вверх стеблей цветущих хризантем. Из такой же резной кости выполнены две крупных хризантемы и три небольших цветка рядом с прорехой в изгороди в нижней части. При этом центральный, наиболее крупный цветок пышной игольчатой хризантемы, подобный распускающийся бутон в правой части, а также три небольших традиционных хризантемы акцентированы мастером используемым для инкрустации материалом - более светлым чем кость перламутром, притягивающим и отражающим лучи света. В верхней части изображения помещена птичка, поймавшая мотылька, фигура которой также выполнена из кости. В изображении птицы обращает на себя внимание тонкость детализации и тонирование оперения крыльев.

Небольшие композиционные изменения, а также иное сочетание цветущих растений отличает левое панно. Здесь мы видим изображение в кости изгороди в виде циновки, закрепленной на жесткой бамбуковой раме. В нижней части сквозь плетенку прорастают цветущие веточки сливы. Три цветка пиона разного размера размещены на вертикальной оси. Верхний полураспустившийся

\footnotetext{
${ }^{1}$ Названия сторон ширмы приводятся условно с целью облегчения сопоставления описания с изображением.
}

Известия УрФУ. Серия 2. Гуманитарные науки. 2019. Т. 21. № 1 (184) 
C. E. Винокуров. Японская экспортная ширма: вторая половина XIX - начало XX в. 231

бутон и центральный цветок, как и все листья, выполнены из кости. Нижний, наиболее крупный цветок пиона, полуприкрытый листом из кости, выполнен из резного перламутра (ил. 3 ).

Инкрустация панелей разными материалами и с разной высотой рельефа позволяет нам отнести ширму к типу лаковых изделий эпохи Мэйдзи в «стиле Сибаяма», предназначенных для экспорта в Европу. Название направления Сибаяма, возникшее в период 1772-1781 гг., восходит к населенному пункту в современной префектуре Тиба - месту рождения и первого этапа творчества знаменитого резчика по кости Оноги Сэндзо (1775-1836). В начале XIX в. именно он начал применять для декора лаковых произведений обильную и дробную инкрустацию разными материалами с целью добиться максимальной декоративности.

Специалисты отмечают, что мастера эпохи Мэйдзи, продолжавшие линию Оноги Сэндзо и работавшие в «стиле Сибаяма», преимущественно ориентировались на европейский вкус [Совершенство в деталях]. В последней трети XIX в. мастера этого направления, работавшие преимущественно в Токио и Иокогама (местах большого скопления европейских торговцев), начинают создавать не только небольшие предметы (коробочки для документов, обильно украшенные перламутром и костью вазы-курильницы), но и крупные сложные произведения (панно, ширмы и кабинеты с инкрустацией). В декоре этих предметов часто представлены сюжетные или пейзажные сцены с высокой степенью натурализма, как и в случае с рассматриваемой нами ширмой. Это стремление к жизнеподобности, наблюдаемое в период Мэйдзи, соответствует принципу, существовавшему в Китае с конца периода Сун (960-1279) и заимствованному впоследствии японской живописью XVI в. (в частности, живописью ширм), обрело свое второе рождение в Японии второй половины XIX в. не без определенной доли влияния европейской школы.

Отдельного внимания заслуживают выполненные из кости с тонировкой традиционным красным цветом печати (ил. 4), располагающиеся в правом и левом углах панелей и состоящие из двух частей. В результате консультаций с переводчиками - как японистами, так и китаистами - было установлено, что воспроизведенные в «печатях» иероглифы являются китайскими. В верхней части (квадратная печать) на данный момент удалось расшифровать три иероглифа: 如海堂 (Жу Хайтан, пиньинь: Ru Haitang), - вероятно, имя художника или мастерской. Вторая прямоугольная часть печати не поддается прочтению полностью, что значительно затрудняет установление связи ширмы с той или иной мастерской ${ }^{2}$ Этот вопрос требует дальнейшего изучения.

В иной технике выполнена «ординарная» сторона ширмы, несущая также иное образное содержание. Так, в верхней и нижней части рам резьбой в невысоком рельефе изображены стебли бамбука - символ долголетия,

\footnotetext{
${ }^{2}$ Автор выражает благодарность сотрудникам Института Конфуция УрФУ К. Б. Лозовской и Цао Ляну за помощь в расшифровке печатей ширмы.
} 
а в боковых - орнамент из ромбов с заключенными в них цветами хризантем. Вертикальные стойки рамы декорированы геометрическим орнаментом в виде ромбов с вписанными в них упрощенными изображениями хризантемы. Панно, выполненные в технике красного лака с элементами золочения, представляют собой живописные композиции в жанре «цветы-птицы», изображающие камерные уголки природы и напоминающие китайскую манеру живописи тушью (в частности, довольно подробное изображение цветов и птиц в сочетании со «скорописным» окружением). Нельзя не отметить, что, в отличие от панно «парадной стороны», композиции панелей «ординарной» стороны являются продолжением друг друга. Эта связь обуславливается характером изображения рельефа местности - холма на левом панно и его продолжения на правом, а также изображением одинаковых птиц (ил. 5).

Использование разных приемов в оформлении ширмы, отличное по своей силе выразительное содержание было направлено на фиксацию внешней «парадной» стороны ширмы и внутренней, предназначенной для «укрытия» владельца от глаз, создания камерного пространства в интерьере. Нельзя не отметить, что такое многодельное произведение с пышным декором и массивной рамой не соответствовало традиционным воззрениям японцев о лаконичности декоративной программы интерьера. Однако этот чрезмерный по японским стандартам декор ширмы идеально вписывался в интерьерную концепцию европейского дома второй половины XIX в. Период неостилей с доминирующим интересом к прихотливым формам и экзотическим материалам второго и третьего рококо стал идеальной площадкой постепенно зарождающегося модерна.

\section{Контекст}

Производство ширм, как и многие виды искусства и типы предметов, берет свое начало в Китае. Традиционно японские ширмы представляют собой несколько скрепленных между собой створок, на рамы которых закреплялись расписные листы бумаги или полотнища шелка и живописные композиции. Функциональная роль ширмы заключалась в вариативности деления пространства, а живописные панно на створках позволяли внести в лаконичный интерьер японского дома дополнительные художественные акценты.

Истории развития и художественным особенностям традиционной японской «живописной» ширмы посвящено немало исследований, практически в каждом из которых указывается ее главная характеристика, соответствующая общему содержанию японской культуры. Так, Н. С. Николаева в мобильности ширмы видит «особый смысл, указывающий на связь вещи с человеком, который может и отгородиться ею от постороннего глаза, и “унести” вещь в другое место, и даже на время как бы ее “уничтожить”, сложив и превратив в единый объем, уже не имеющий никаких полезных функций» [Николаева, 2003, с. 184].

C XVI в. - времени первых контактов Японии и стран Европы - сразу закрепляется популярность на западном рынке произведений, декорированных 
в традиционной технике - уруси. Словом «уруси» в Японии обозначаются произведения лакового искусства. С началом Нового времени в интерьеры европейских домов проникают лаковые произведения, ставшие визитной карточкой экзотической островной страны и получившие, по аналогии с ранним обозначением китайского фарфора («china»), название «јарап». Первыми предметами лака в странах Европы были различные коробочки и шкатулки. Со временем, под влиянием нарастающей популярности лаковых изделий, формат работ меняется. На европейский рынок экспортируются все более крупные предметы с усложняющимся декором: от небольших столиков до многодверных кабинетов и массивных многостворчатых ширм.

Складывавшийся на протяжении столетий художественный язык японской ширмы резко меняется во второй половине XIX в., адаптируясь к вкусу европейского потребителя. Эпоха Мэйдзи (1868-1912) - уникальный период в истории взаимоотношений Японии и Европы, характеризующийся выходом из более чем двухсотлетней изоляции островного государства и тотальным столкновением разных типов культур, в искусстве западноевропейских стран выразившимся в широкоизвестном и не раз описанном явлении - «японизме». Отметим, что тесное знакомство европейцев с предметами японского искусства начинается раньше благодаря привозимым из Японии коллекциям европейских путешественников, публикациям первых западных трудов по истории Японии, а также росту интереса к японской ксилографии, использовавшейся в качестве иллюстраций в этих трудах.

Отдельно стоит упомянуть участие произведений японских мастеров во Всемирных выставках, являвшихся площадкой для знакомства и взаимного обмена художественными достижениями для разных стран, а также одним из важных источников формирования музейных и частных собраний [Винокуров, Будрина]. Так, в официальных изданиях первой Всемирной выставки 1851 г. в Лондоне мы находим указания на то, что голландской фирмой Ф. Зеегерса была представлена японская ширма [The Official Descriptive..., p. 1148; Report by the Juries..., p. 1209]. Отдельные произведения искусства страны Восходящего Солнца были экспонированы и на последующих многочисленных выставках (в 1854 и 1862 г. - в Лондоне, в 1867 г. - в Париже), вплоть до первого официального, под покровительством японского императора, участия в выставке 1873 г. в Вене, где были высоко отмечены произведения из бронзы и лаки [Kunst und Kunstgewerbe..., S. 174-180], а фарфор и текстиль подверглись критике [Jahn, p. 51].

Однако не только Европа испытала сильное воздействие экзотической дальневосточной культуры. В искусстве Японии также происходят сложные процессы - от усвоения норм и принципов западной художественной системы в начале эпохе Мэйдзи до осознания необходимости сохранения традиционной древней культуры. В последние десятилетия XIX в. эта борьба «старого традиционного» и «нового иноземного», отражающаяся практически во всех областях японской культуры, наиболее ярко проявилась в декоративно-прикладном 
искусстве. Описывая процесс развития «японизма» в Европе, исследователи отмечают [Николаева, 1996, с. 229], что, в отличие от художников, интересовавшихся печатной графикой, широкая публика проявила интерес к «японскому» в предметных формах. Любопытно отметить, что подобный процесс наблюдается и в Японии: здесь именно прикладное искусство испытывает на себе сильное влияние европейского вкуса и стремится соответствовать запросу западного рынка. Традиционно популярные в Европе отрасли японского производства начинают подстраиваться под экспортные механизмы, что приводит к парадоксальной ситуации: европейцы считали приобретаемые предметы подлинно японскими, а сами японцы, создавая их в европейском вкусе, видели их несоответствие традициям национальной культуры.

Обозначенное влияние европейского вкуса на все виды искусства Японии привело в 1870-1880-е гг. к реакции и попыткам возвращения к национальным традициям. В прикладном искусстве это выразилось в публикации официальных рекомендованных образцов для мастеров-прикладников [Совершенство в деталях, с. 18]. Этот ход правительства, с одной стороны, был направлен на упрощение и ускорение работы мастеров, обеспечивавших все возрастающий спрос, а с другой - способствовал возвращению к традиционным формам, композиционным приемам и сюжетам в создаваемых произведениях. Такое внимание государства к деятельности мастеров, проявившееся в определенного рода унификации и попытке придания единообразия экспортным произведениям, объясняет композиционное сходство, доходящее до прямых повторов в разных предметах.

\section{Провенанс}

Как указывалось ранее, отсутствие точной информации позволяет лишь предположить возможный путь поступления предмета в коллекцию семьи Басевич, исходя из контекста эпохи и общих тенденций в формировании коллекций дальневосточного искусства в России и Европе второй половины XIX - первой половины XX в., а также хитросплетений биографии самой К. К. Басевич.

Из биографии, подготовленной внучатой племянницей коллекционера P. М. Лотарёвой, мы узнаем, что отец Казимиры Константиновны Басевич (в девичестве Романовской) принадлежал к семье ссыльных польских дворян, отправленной в Иркутск после подавления польского восстания 1863-1864 гг. Позднее семья переехала в Харбин, откуда в 1917 г. К. К. Басевич приезжает в Москву и поступает на Высшие женские курсы. Далее в биографии коллекционера будут упомянуты еще несколько городов уже Советского Союза - Иркутск, Владикавказ, Ташкент и, скорее всего, уже после реэвакуации во второй половине 1940-х гг. - Ленинград [ОР ГТГ, ф. 4, д. 3298].

Несмотря на возможность приобретения ширмы еще во время проживания в Иркутске (одном из центров торгового пути из Китая) или Харбине, наиболее вероятным местом приобретения ширмы представляется Ленинград и его 


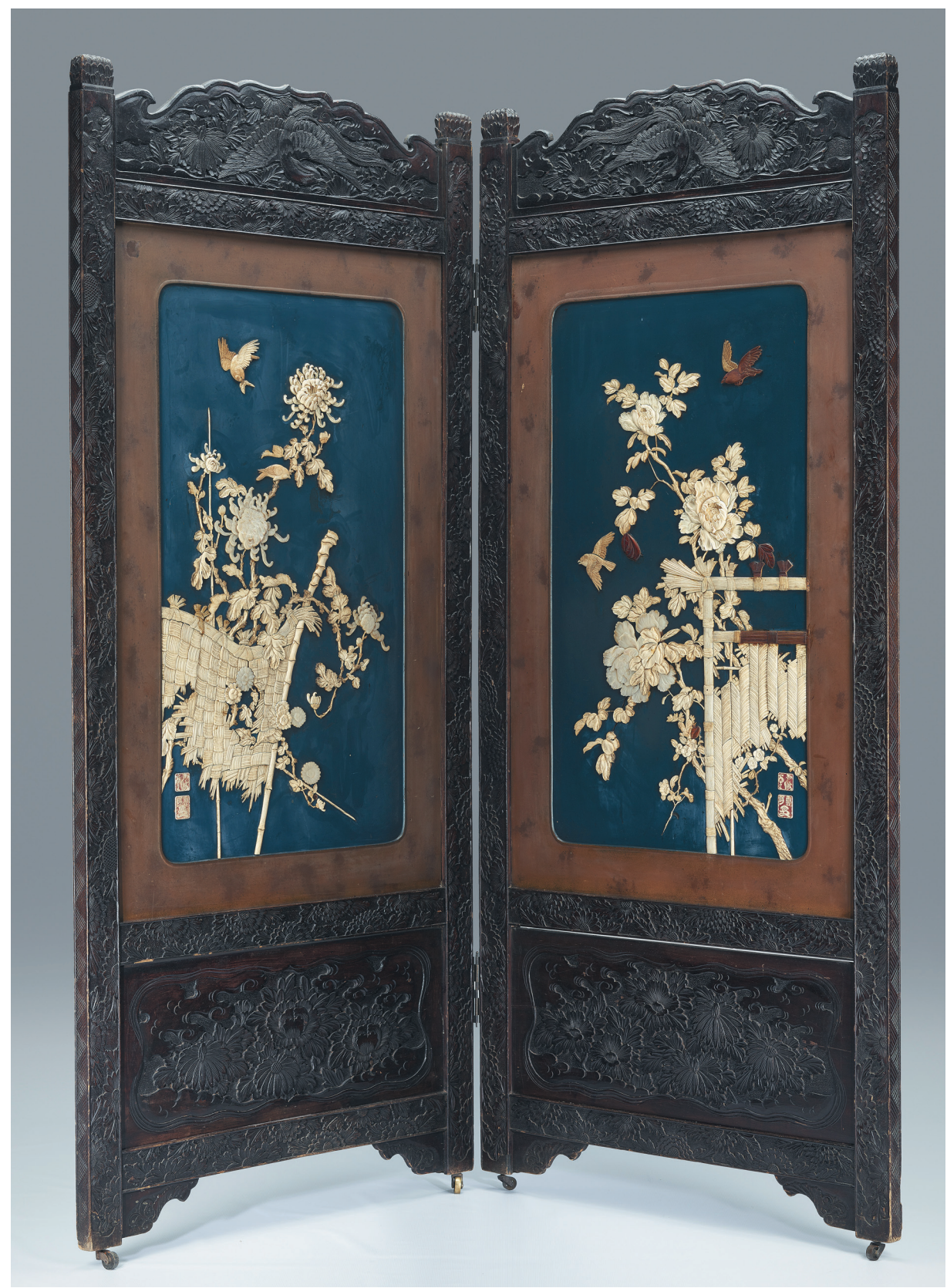

1. Ширма («парадная» сторона). Япония, вторая половина XIX - начало XX в. Дерево, металл, лак, кость, перламутр; резьба, иро-уруси, инкрустация. Екатеринбургский музей изобразительных искусств

Screen (front side). Japan, $2^{\text {nd }}$ half of the $19^{\text {th }}$ - early $20^{\text {th }}$ centuries. Wood, metal, varnish, ivory, mother of pearl; carving, iro-urushi, inlay. Yekaterinburg Museum of Fine Arts 


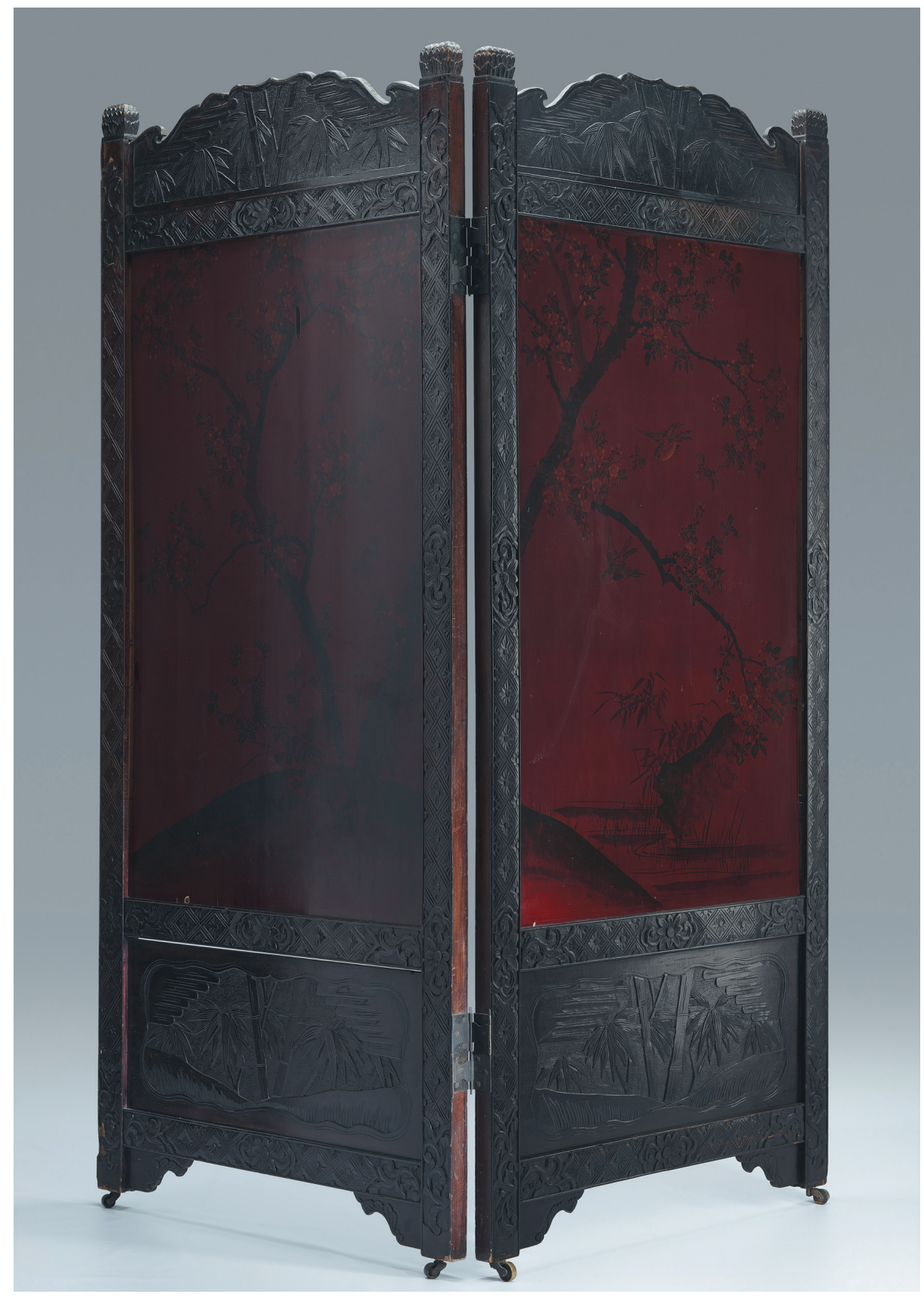

2. Ширма («ординарная» сторона). Дерево, металл, лак; резьба, иро-уруси, хирамаки-э, роспись. Екатеринбургский музей изобразительных искусств Screen (back side). Wood, metal, varnish; carving, iro-urushi, hiramaki-e, painting. Yekaterinburg Museum of Fine Arts 


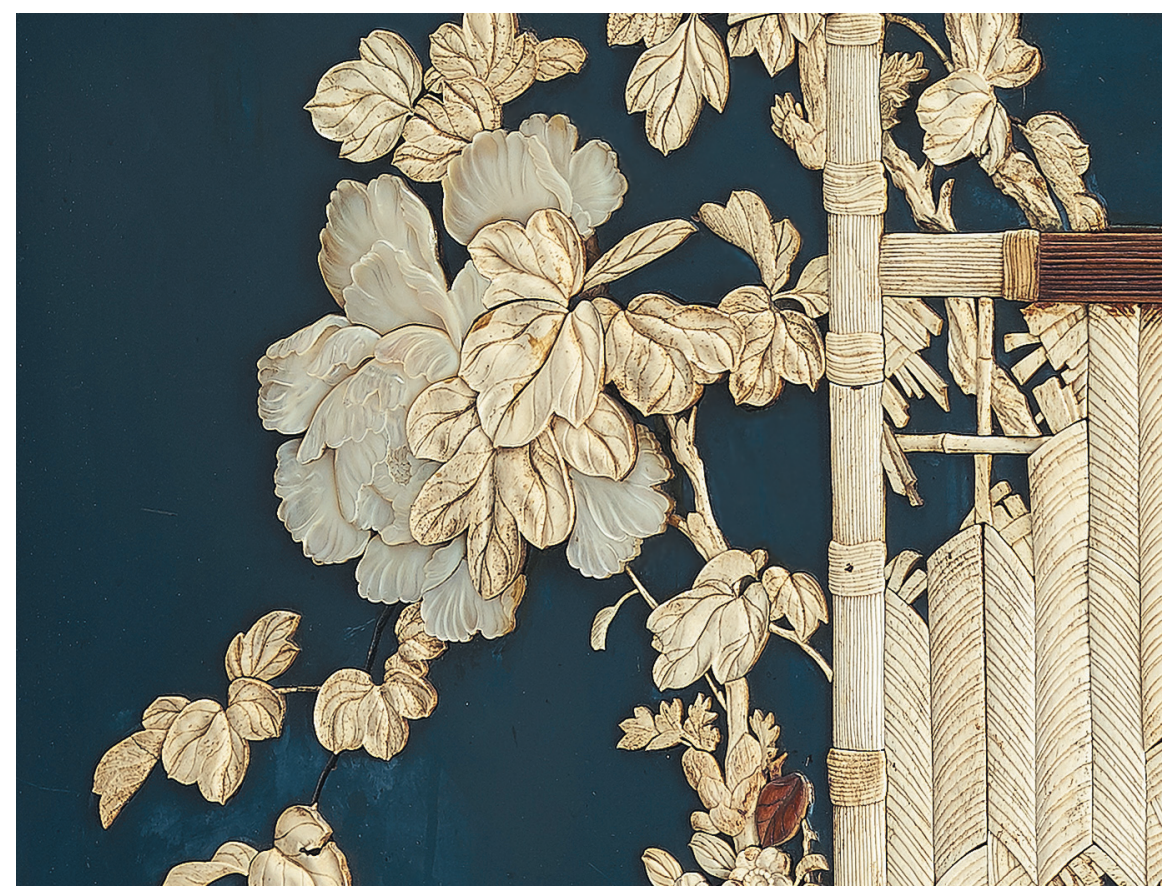

3. Фрагмент ширмы. Инкрустация резными перламутром и костью Screen fragment. Inlay with carved mother of pearl and ivory

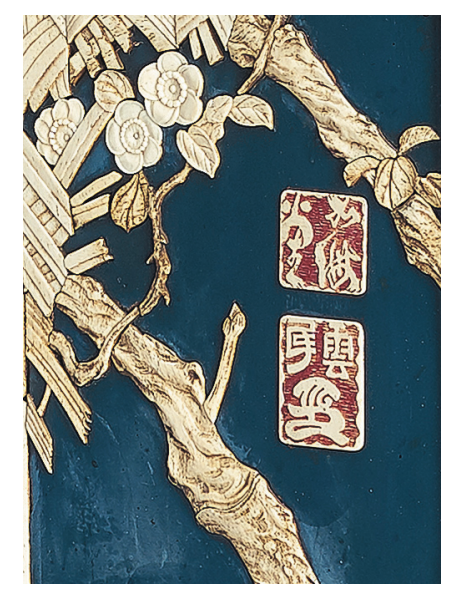

4. Фрагмент ширмы. Печати Screen fragment. Stamps 

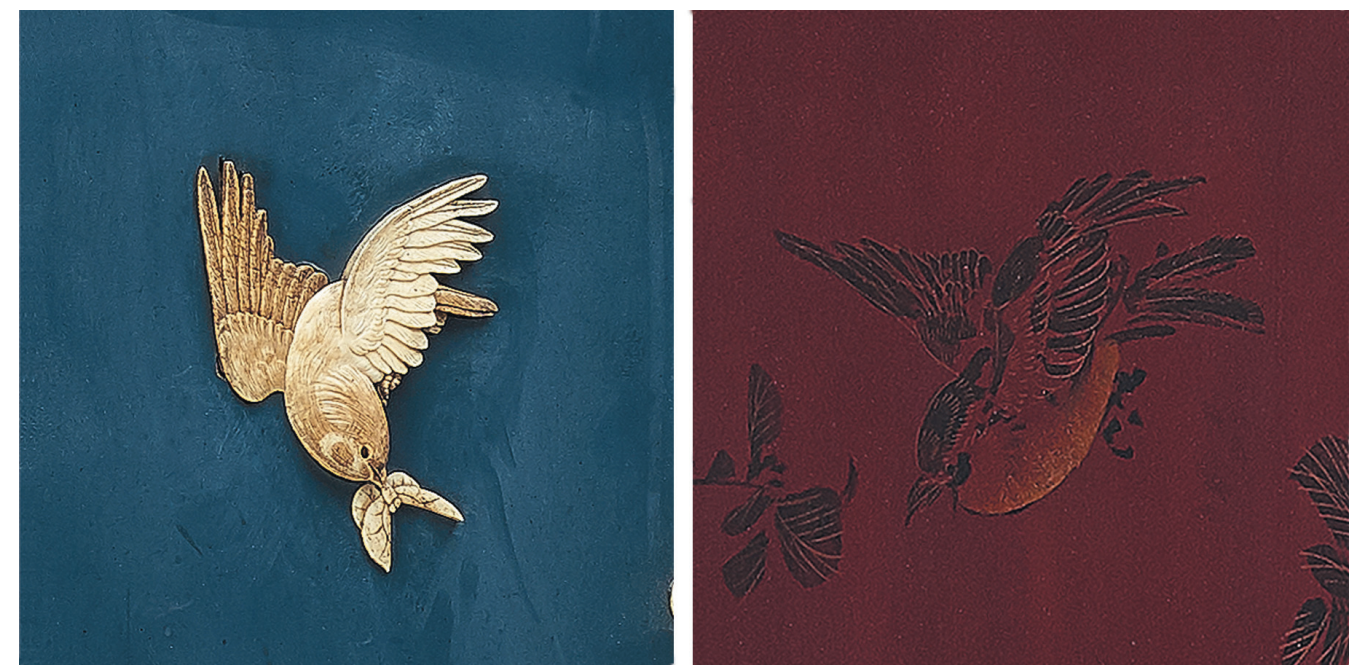

5. Фрагменты ширмы. Изображения птиц

Screen fragment. Birds

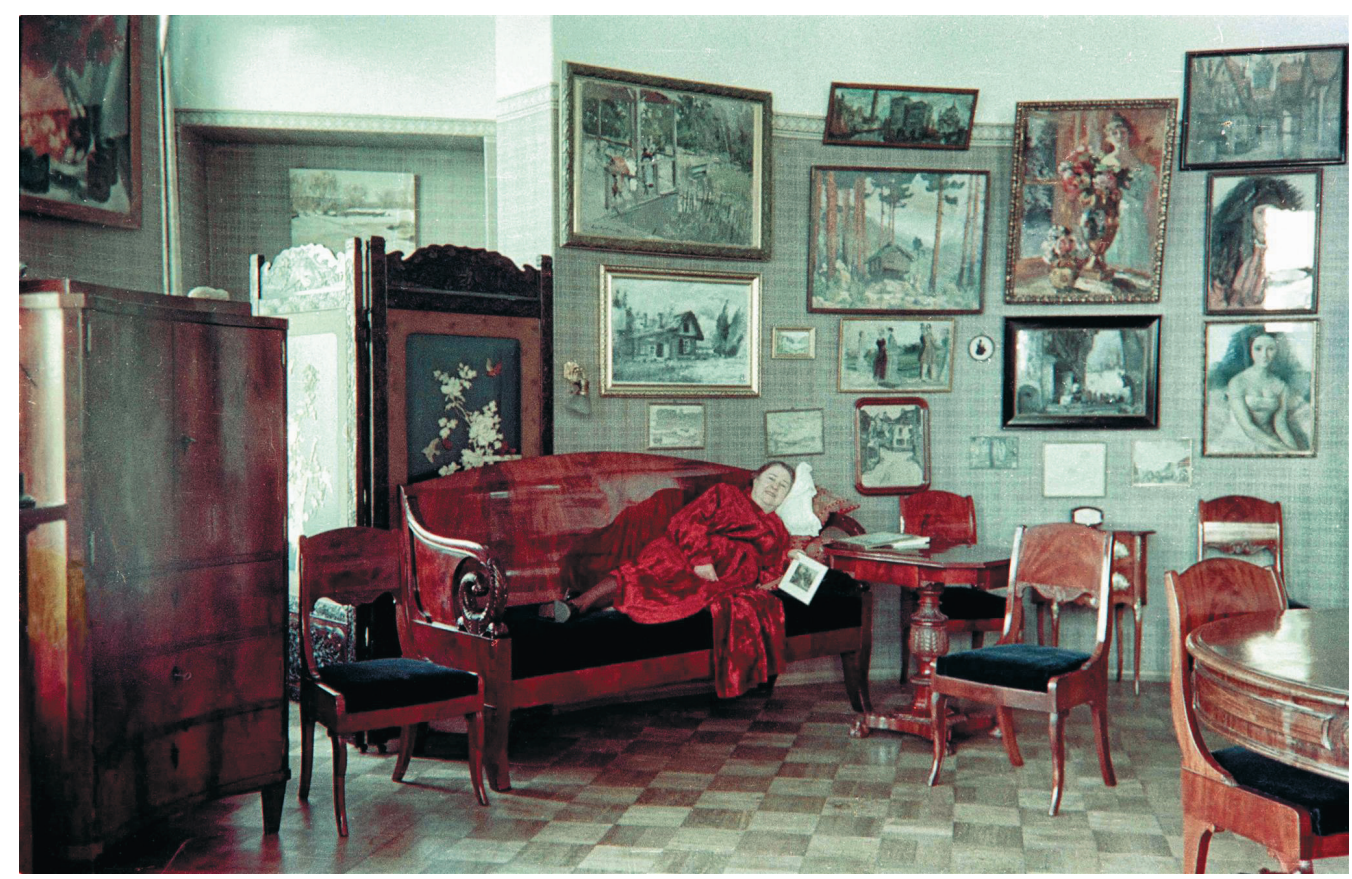

6. К. К. Басевич в ленинградской квартире. 1961.

Фото из архива К. К. Басевич, Г. И. и Р. М. Лотарёвых

K. K. Basewicz in her Leningrad flat. 1961.

Photograph from the archive of K. K. Basewicz, G. I. and R. M. Lotaryov 
антикварный рынок конца 1940-1950-х гг. Известно, что Санкт-Петербург на рубеже веков переживал настоящий «японский бум», не прервавшийся даже в годы Русско-японской войны (1904-1905) и отчасти напоминавший французский японизм последней трети XIX в. В это время в столице организовывались выставки и аукционные торги с произведениями японского искусства, выходили многочисленные публикации путешественников и журналистов, посетивших Японию [Николаева, 1996; Завьялова; Мельников]. Отметим, что в художественной сфере, вопреки преобладающему вниманию к японской гравюре как источнику влияния на европейское и русское искусство и формирование стиля модерн, не меньший интерес проявлялся и к произведениям мастеровприкладников страны Восходящего Солнца. Поступавшие из Японии бронза, фарфор, лаки, мебель также становились источником вдохновения российских художников. Примером этого может служить произведение Императорской Петергофской гранильной фабрики - созданная в конце 1880-х гг. агатовая ваза с дельфинами в японской стилистике, источником для которой послужила публикация японской художественной бронзы во французском журнале «LArt pour tous: encyclopédie de l'art industriel et décoratif» [Винокуров].

Отдельно стоит упомянуть характер складывания дальневосточных коллекций, на рубеже веков нередко формировавшихся не прямым путем «Япония - Россия» или «Китай - Россия», а посредством приобретения предметов в европейских (в первую очередь французских) магазинах и художественных салонах (среди которых были особенно известны «La Porte chinoise», «La maison Sichel», магазин-салон Самюэля Бинга и др.) [Пронина; Николаева, 1996]. Таким образом, в начале XX в. в Санкт-Петербурге складываются крупные собрания дальневосточного искусства, которые в результате революционных событий в первые десятилетия советской власти оказались либо национализированными и перешли в собрания новых государственных музеев, либо подверглись распылению через многочисленные комиссионные и антикварные магазины.

С большой долей уверенности можно предположить, что японская ширма, поступившая в собрание Екатеринбургского музея изобразительных искусств в 2017 г., могла быть приобретена семьей Басевич в одном из комиссионных магазинов уже после переезда в Ленинград. Не имея точной даты переезда (конец 1940-х - начало 1950-х гг.), мы можем говорить о крайней датировке 1961 г. Эта дата обуславливается наличием фотографии интерьера квартиры (ил. 6), сделанной в 1961 г., на которой мы видим как ширму, так и полотно К. Д. Коровина «Натюрморт с портретом В. В. Перцовой», переданное в декабре 1961 г. в собрание Государственной Третьяковской галереи.

Таким образом, изученный предмет, его художественные и технологические особенности, а также сложный провенанс укладываются в концепцию прозрачности культурных границ рубежа веков. Традиционная японская технология инкрустации лака под влиянием европейского вкуса претерпевает изменения, приведшие к формированию особого направления в прикладном искусстве 
страны Восходящего Солнца. Эта адаптация традиционной манеры становится залогом чрезвычайной популярности подобных изделий в Европе. Европейская мода на «японское» провоцирует власти Японии на ответную реакцию. Она выразилась, с одной стороны, в осознании необходимости сохранения национальной идентичности, а с другой - в создании официальной художественной программы для произведений экспортного характера. Таким образом, была предпринята попытка поиска компромисса между требованиями традиционной культуры и вкусами и запросами европейского рынка.

\section{Источники}

ОР ГТГ. Ф. 4. Д. 3298 [Лотарева Р. М. Жизнь в искусстве. Екатеринбург, 2008-2018. Рукопись ].

\section{Исследования}

Винокуров С. Е. На пороге нового стиля. Источники дальневосточных реминисценций в работах российских камнерезов 1880-1900-х гг. // Модерн в России. Накануне перемен : материалы ХХІІІ Царскосельской науч. конф. / под ред. И. К. Ботт. СПб. : Серебряный век, 2017. С. 105-113.

Винокуров С. Е., Будрина Л. А. Всемирные выставки второй половины XIX века как один из источников китайских реминисценций в отечественном камнерезном искусстве // Изв. Урал. федер. ун-та. Сер. 2 : Гуманитар. науки. 2017. Т. 19. № 1 (160). С. 62-74. https://doi.org/10.15826/ izv2.2017.19.1.005

Владелица Красного коня. Дар Казимиры Басевич музеям России. Екатеринбургский музей изобразительных искусств 10 августа - 30 сентября 2018. Издание к выставке / сост. Т. А. Юдкевич, 3. Ю. Таюрова. Екатеринбург : ЕМИИ, 2018.

Завьялова А. Е. Мир искусства. Японизм / Рос. акад. художеств, Науч.-исслед. ин-т теории и истории изобразительных искусств. М. : БуксМАрт, 2014.

Мельников В. Л. Семья Рерихов и Япония: открытость культурного полилога // Международная научно-практическая конференция «Рериховское наследие». Т. ХІІІ : История изучения Азии. Новые открытия. От Серебряного века русской культуры к современности / [отв. ред. А. А. Бондаренко, В. Л. Мельников]. СПб. : Изд. СПбГБУК «Музей-институт семьи Рерихов», 2014. C. $185-243$.

Николаева Н. С. Япония - Европа. Диалог в искусстве. Середина XVI - начало XX века. М. : Изобраз. искусство, 1996.

Николаева Н. С. Ширма - вещь и картина // Вещь в японской культуре : [сб. ст.] / Центр по изучению соврем. Японии ; [сост. Н. Г. Анарина, Е. М. Дьяконова]. М. : Вост. лит., 2003. С. 169-184.

Пронина М. Г. Половцовы как создатели восточной коллекции музея ЦУТР барона А. Л. Штиглица // Изв. Урал. федер. ун-та. Сер. 2 : Гуманитар. науки. 2015. Т. 17. № 2 (139). C. $36-43$.

Совершенство в деталях. Искусство Японии эпохи Мэйдзи, 1868-1912 : частная коллекция : каталог выставки : [в 4 т.] / Гос. Эрмитаж ; [авторы концепции, кураторы выставки, научные редакторы и авторы вступительных статей: А. В. Савельева, М. Л. Меньшикова]. СПб. : Чистый лист, 2016. Т. 1 : Лаки.

Auer H., Lützow C. von. Kunst und Kunstgewerbe auf der Wiener Weltausstellung. Leipzig : Verl. von E. A. Seemann, 1875.

Jahn G. Meiji Ceramics: The Art of Japanese Export Porcelain and Satsuma Ware, 1868-1912. Stuttgart : Arnoldsche, 2004.

Reports by the Juries on the Subjects in the Thirty Classes into Which the Exhibition Was Divided: Exhibition of the Works of Industry of All Nations, 1851. London : Spicer Brothers, 1852. 
C. Е. Винокуров. Японская экспортная ширма: вторая половина XIX - начало XX в. 237

The Official Descriptive and Illustrated Catalogue of the Great Exhibition of the Works of Industry of All Nations. London : Spicer Brothers, 1851.

\section{References}

Auer, H., \& Lützow, C. von (1875). Kunst und Kunstgewerbe auf der Wiener Weltausstellung. Leipzig: Verlag von E. A. Seemann. (In Deutsch)

Jahn, G. (2004). Meiji Ceramics: The Art of Japanese Export Porcelain and Satsuma Ware, 18681912. Stuttgart: Arnoldsche.

Mel'nikov, V. L. (2014). Sem'ia Rerikhov i Iaponiia: otkrytost' kul'turnogo poliloga [The Roerich Family and Japan: The Openness of Cultural Polylogue]. In A. A. Bondarenko, \& V. L. Mel'nikov (Eds.), Mezhdunarodnaia nauchno-prakticheskaia konferentsiia "Rerikhovskoe nasledie". T. XIII:Istoriia izucheniia Azii. Novye otkrytiia. Ot Serebrianogo veka russkoi kul'tury k sovremennosti [International Scholarly Practical Conference "Roerich Heritage". Vol. 13: History of the Study of Asia. New Discoveries. From the Silver Age of Russian Culture to the Present] (pp. 185-243). St Petersburg: Izdanie SPbGBUK “Muzei-institut sem'i Rerikhov". (In Russian)

Nikolaeva, N. S. (1996). Iaponiia - Evropa. Dialog v iskusstve. Seredina XVI - nachalo XX veka [Japan - Europe. Dialogue in Art. Mid-16 ${ }^{\text {th }}-$ Early 20 ${ }^{\text {th }}$ Centuries]. Moscow: Izobraz. iskusstvo. (In Russian)

Nikolaeva, N. S. (2003). Shirma - veshch' i kartina [The Screen as an Object and a Picture]. In N. G. Anarina, \& E. M. Dyakonova (Comp.), Veshch'v iaponskoi kul'ture [Things in Japanese Culture] (pp. 169-184). Moscow: Vostochnaia literatura. (In Russian)

Pronina, M. G. (2015). Polovtsovy kak sozdateli vostochnoi kollektsii muzeia TsUTR barona A. L. Shtiglitsa [The Polovtsov Family as Founders of Eastern Art Collection in the Museum of Baron Stieglitz' School of Technical Drawing]. Izvestia. Ural Federal University Journal. Series 2: Humanities and Arts, 17, 2 (139), 36-43. (In Russian)

Reports by the Juries on the Subjects in the Thirty Classes into Which the Exhibition Was Divided: Exhibition of the Works of Industry of All Nations, 1851. (1852). London: Spicer Brothers.

Savelyeva, A. V., \& Men'shikova, M. L. (2016). Sovershenstvo v detaliakh. Iskusstvo Iaponii epokhi Meidzi (1868-1912): chastnaia kollektsia: katalog vystavki [Perfection in Details. The Japanese Art of the Meiji Period (1868-1912): Private Collection: Catalogue of the Exhibition] (Vols. 1-4). (Vol. 1: Laki [Lacquers]). St Petersburg: Chistyi list. (In Russian)

The Official Descriptive and Illustrated Catalogue of the Great Exhibition of the Works of Industry of All Nations. (1851). London: Spicer Brothers.

Vinokurov, S. Ye. (2017). Na poroge novogo stilia. Istochniki dal'nevostochnykh reministsentsii v rabotakh rossiiskikh kamnerezov 1880-1900-kh gg. [On the Threshold of a New Style. Sources of Far Eastern Reminiscences in the Works of Russian Stone-cutters of 1880-1900]. In I. K. Bott (Ed.), Modern v Rossii. Nakanune peremen. Materialy XXIII Tsarskosel'skoi nauchnoi konferentsii [Modern in Russia. On the Eve of Change. Materials of 23 Tsarskoye Selo Scholarly Conference] (pp. 105-113). St Petersburg: Serebryanyi vek. (In Russian)

Vinokurov, S. Ye., \& Budrina, L. A. (2017). Vsemirnye vystavki vtoroi poloviny XIX veka kak odin iz istochnikov kitaiskikh reministsentsii v otechestvennom kamnereznom iskusstve [World Exhibitions of the Second Half of the $19^{\text {th }}$ Century as One of the Sources of Chinese Reminiscences in Russian Stone-cutting Art]. Izvestia. Ural Federal University Journal. Series 2: Humanities and Arts, 19, 1 (160), 62-74. https://doi.org/10.15826/izv2.2017.19.1.005 (In Russian)

Yudkevich, T. A., \& Tayurova, Z. Yu. (Comp.). (2018). Vladelitsa Krasnogo konia. Dar Kazimiry Basevich muzeiam Rossii. Ekaterinburgskii muzei izobrazitel'nykh iskusstv, 10 avgusta - 30 sentiabria 2018. Izdanie $k$ vystavke [The Owner of the Red Horse. Kazimira Basewicz's Donations to Russian Museums. Yekaterinburg Museum of Fine Arts, 10 August - 30 September, 2018. Edition for the Exhibition]. Yekaterinburg: EMII. (In Russian) 
Zavyalova, A. E. (2014). Mir iskusstva. Iaponizm [The World of Art. Japonism]. Moscow: BuksMArt. (In Russian)

\section{Винокуров Сергей Евгеньевич} заведующий отделом по работе с посетителями, Екатеринбургский музей изобразительных искусств;

620014, Екатеринбург, Воеводина, 5 аспирант кафедры истории искусств и музееведения

Уральский федеральный университет 620000, Екатеринбург, пр. Ленина, 51

E-mail: serg.vinokuroff@gmail.com

\section{Vinokurov, Sergey Yevgenyevich}

Head of the Visitors Department, Yekaterinburg Museum of Fine Arts

5, Voevodin Str., 620014 Yekaterinburg, Russia

Postgraduate Student

Department of Art History and Museum

Studies

Ural Federal University

51, Lenin Ave., 620000 Yekaterinburg, Russia

Email: serg.vinokuroff@gmail.com

ORCID: 0000-0001-7548-8651 